Article

\title{
Improving Yield and Quality of Processing Tomato (Lycopersicon esculentum Miller) Using Alternate Partial Root-Zone Drip Irrigation in Arid Northwest China
}

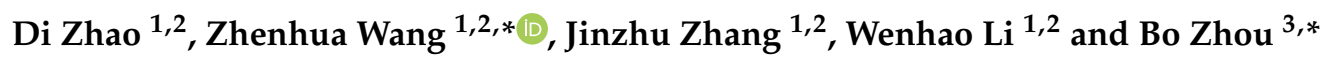 \\ 1 College of Water Resources and Architectural Engineering, Shihezi University, Shihezi 832000, China \\ 2 Key Laboratory of Modern Water-Saving Irrigation of Xinjiang Production and Construction Corps, \\ Shihezi University, Shihezi 832000, China \\ 3 College of Water Resources and Civil Engineering, China Agricultural University, Beijing 100083, China \\ * Correspondence: wzh2002027@163.com (Z.W.); zhoubo1989@cau.edu.cn (B.Z.)
}

Received: 26 June 2019; Accepted: 17 July 2019; Published: 20 July 2019

\begin{abstract}
Processing tomato is one of the most important economic crops in Xinjiang, China, which was constrained with severe water shortage and extreme arid climate. Alternate partial root-zone irrigation (APRI) may provide an effective way to increase irrigation water use efficiency (iWUE) without yield reduction. However, limited studies concerned about applying APRI in processing tomato plantation have been done, especially combined with drip irrigation to further control the irrigation and improve iWUE. Therefore, the two-year pot experiments were conducted to study the effects of different irrigation treatments, including three APRI treatments (irrigation quota of 67.5, 51.6, and $43.7 \mathrm{~mm}$, respectively), fixed partial root-zoon drip irrigation (FPRI, $67.5 \mathrm{~mm}$ ) and conventional drip irrigation (CDI, $67.5 \mathrm{~mm}$ ). The results indicated that APRI was an appropriate irrigation method in processing tomato plantation in arid desert area such as Xinjiang, as high irrigation quota of APRI (APRIH) significantly improved its yield without fruit quality reduction in comparison with those of CDI. However, the yield without fruit quality of FPRI significantly decreased. Even if the irrigation quota of APRI decreased to the medium level (APRIM, $51.6 \mathrm{~mm}$ ), iWUE by increased $31.8-32.7 \%$ on the contrary, as irrigation water was saved by $23.6 \%$; while keeping the yield and fruit quality. Therefore, APRIM is recommended for processing tomato plantation in arid northwest China, to increase plant growth, fruit quality, yield, and iWUE synergistically.
\end{abstract}

Keywords: processing tomato; alternate root-zone drip irrigation; plant growth; physiological characteristics; fruit quality; yield and irrigation water use efficiency

\section{Introduction}

Xinjiang is the largest processing tomato production place in China and ranks as the world's third largest with the exporting proportion being more than $30 \%$ of global trade [1]. Nowadays the annual planting area maintains stable which exceeding $46,667 \mathrm{hm}^{2}$ [2], taking advantages of the sufficient solar radiation and illumination, the large temperature difference between day and night, and the high effective accumulated temperature in local area. These factors are beneficial for processing tomato growth and development, accumulation of dry matter, improvement of soluble solids and production of lycopene [1]. However, due to the extreme water shortage and arid desert climate in Xinjiang, applying high-efficiency water-saving irrigation is critical to sustainable processing tomato production [3]. 
Alternate partial root-zone irrigation (APRI) is regarded as a new water-saving irrigation technology, as by applying it, half of the root-zone is irrigated while the other half is controlled as dry, and then switched with regulated pattern $[4,5]$. Under this condition, the plants would response as partial stomatal closure, reduced leaf initiation, expansion rates, and transpiration efficiency without significant impact on photosynthesis, thus increasing irrigation water use efficiency (iWUE) and lycopene [6]. These reactions depend on the biochemical signals, including plant growth regulators and other chemicals those derived from roots or recycled from shoots in response to dry soil $[7,8]$. Previous studies have demonstrated that APRI would save large amounts of irrigation water compared to traditional irrigation and maintain crop yields and improves water use efficiency, using furrow irrigation or drip irrigation on cotton [9], apple [10-12], pear [13], maize [14,15], grapes [16,17], pomegranate [18], sugar beet [19], eggplant [5], potato [20] and tomato [21,22]. However, there were limited studies reported applying APRI in processing tomato, especially combined with drip irrigation in the arid area.

Therefore, by carrying out the pot experiments with APRI and drip irrigation applied in processing tomato plantation to accurately control the irrigation quota, the objectives of this paper were to study (1) whether APRI combined with drip irrigation technology suitable for planting processing tomato in the typical arid area such as Xinjiang? (2) What is the appropriate irrigation mode if it is suitable? Their answers would be concluded with comprehensive consideration of the effects of different treatments on processing tomato quality, yield and iWUE. The results obtained in this paper would provide theoretical references to processing tomato plantation.

\section{Materials and Methods}

\subsection{Experimental Location}

The pot experiments were conducted in the Key Laboratory of Modern Water-Saving Irrigation of the Xinjiang Production and Construction Corps $\left(44^{\circ} 19^{\prime} \mathrm{N}, 85^{\circ} 59^{\prime} \mathrm{E}, 412 \mathrm{~m}\right.$ above sea level) at Shihezi City, Xinjiang (Figure 1). Local climate is the typical arid continental climate and the experiments were carried out in 2017 and 2018. Air temperature, rainfall data were recorded by an automatic weather station (type: TRM-ZS2; manufacturer: Jinzhou Sunshine Meteorological Technology CO.LTD, Jinzhou, China) located $100 \mathrm{~m}$ away from the experimental location. The total rainfall in 2017 was $96.8 \mathrm{~mm}$, and the temperature ranged from 10.1 to $32.9^{\circ} \mathrm{C}$; while the total rainfall in 2018 was $77.6 \mathrm{~mm}$, and the temperature ranged from 9.6 to $30.78^{\circ} \mathrm{C}$ (Figure 2). The physical and chemical properties of the soil are shown in Table 1.

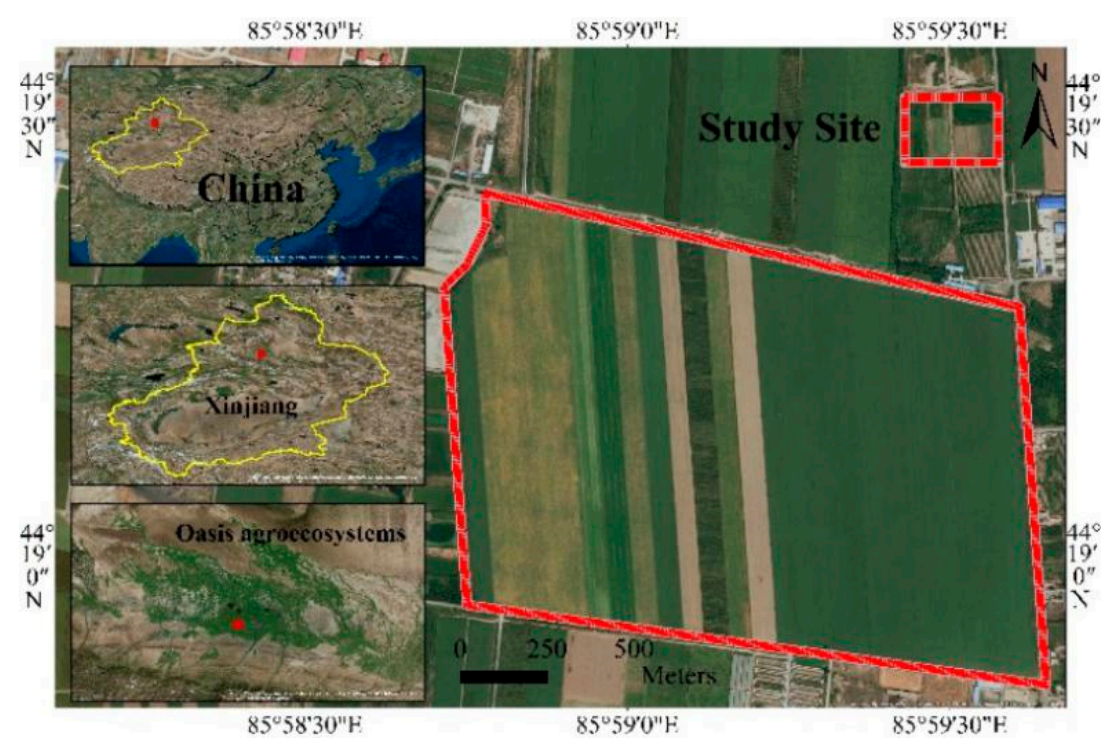

Figure 1. The experimental location. 


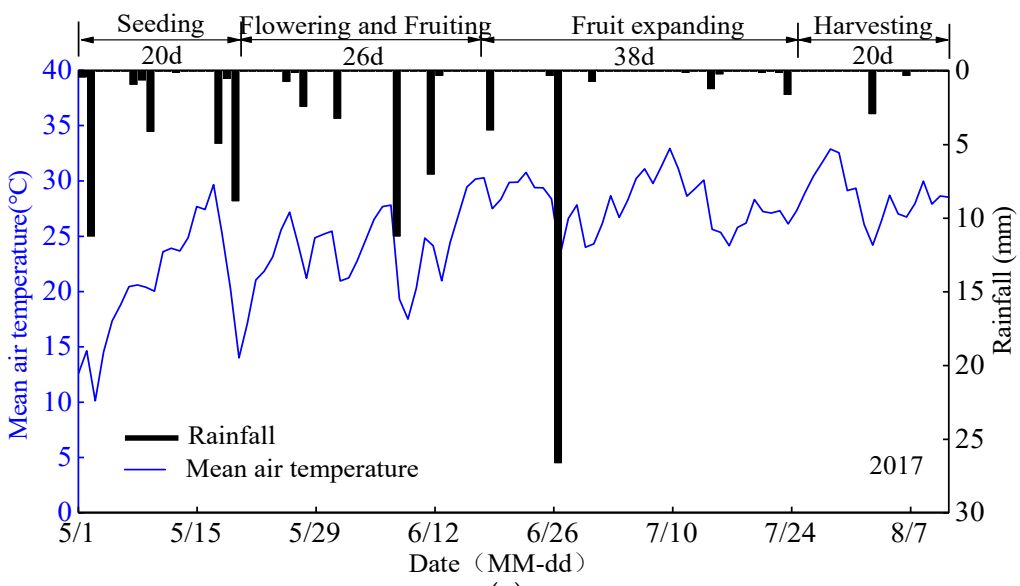

(a)

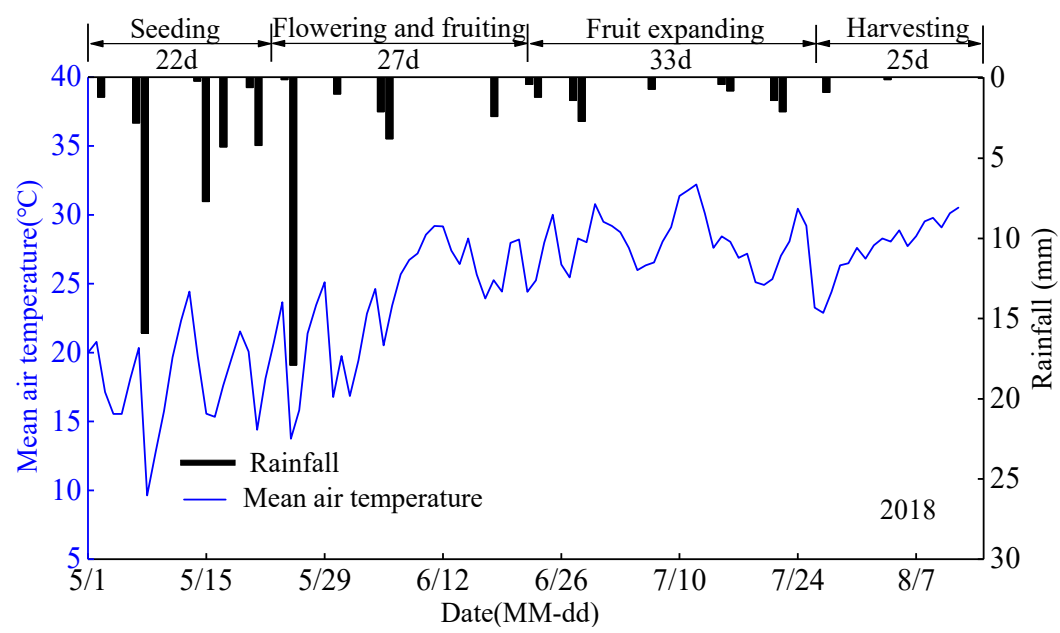

(b)

Figure 2. Distribution of precipitation and air temperature in 2017 and 2018 during the experiments. Note: Figure (a) showed the precipitation and air temperature in 2017, and figure (b) showed the precipitation and air temperature in 2018

Table 1. Soil properties used in the pot experiments.

\begin{tabular}{ccccccccc}
\hline Year & $\mathbf{p H}$ & Soil Type & $\begin{array}{c}\text { Unit Weight } \\
\left(\mathbf{g ~ m}^{-3}\right)\end{array}$ & $\begin{array}{c}\text { Organic Matter } \\
\left(\mathbf{g ~ k g}^{-\mathbf{1}}\right)\end{array}$ & $\begin{array}{c}\text { Total N } \\
\left(\mathbf{g ~ k g}^{-\mathbf{1}}\right)\end{array}$ & $\begin{array}{c}\text { Available N } \\
\left(\mathbf{m g ~ k g}^{-\mathbf{1}}\right)\end{array}$ & $\begin{array}{c}\text { Available P } \\
\left(\mathbf{m g ~ k g}^{-1}\right)\end{array}$ & $\begin{array}{c}\text { Available K } \\
\left(\mathbf{m g ~ k g}^{-1}\right)\end{array}$ \\
\hline 2017 & 7.5 & middle loam & 1.42 & 17.88 & 1.32 & 52.44 & 24.66 & 187.33 \\
2018 & 7.3 & middle loam & 1.43 & 16.54 & 1.21 & 51.32 & 23.68 & 179.65 \\
\hline
\end{tabular}

Note: The experiment soil was Middle loam which was distinguished by soil texture. Middle loam is a type of loam. It consists of powders of different thicknesses, and the sand and clay content are roughly the same, with a slight roughness. It has plasticity and can be twisted into small strips with a diameter of about $3 \mathrm{~mm}$, but it is easy to break when bent into an arc of 2 to $3 \mathrm{~cm}$.

\subsection{Experimental Design}

The pot experiments used the plastic films to separate different root zones (Figure 3). Irrigation methods included conventional drip irrigation (CDI), fixed partial root-zoon drip irrigation (FPRI), and three levels of alternate partial root-zoon drip irrigation (including high irrigation quota, APRIH; medium irrigation quota, APRIM; and low irrigation quota, APRIL). There were five treatments included in the experiment and the specific irrigation schedules are shown in Table 2. Each treatment had three replications, and a total of fifteen pots. The processing tomato planted for two consecutive years was "JinFan 3166" (The main stem is $70 \mathrm{~cm}$ to $75 \mathrm{~cm}$, and the fruit has an elliptical shape with good hardness and is not easy to crack. The average fruit weight ranges from $75 \mathrm{~g}$ to $85 \mathrm{~g}$. Under high 
temperature and climatic conditions, the ability to continuously flower and fruit is strong, and the heat resistance is strong. The first growth cycle yields $1.44 \times 10^{5} \mathrm{~kg} / \mathrm{hm}^{-2}$, and the second growth cycle yields $1.29 \times 10^{5} \mathrm{~kg} / \mathrm{hm}^{-2}$ ), which was transplanted on 1 May with the height of about $13 \mathrm{~cm}$. It entered the flowering period on 1 June, as the first flower all opened on 9 June and the second flower began to bloom on 12 June. The experiments ended on 12 August, lasting 104 days. In 2017 and 2018, the treatments were the same. During the flowering period within one month after transplanting, whole irrigation was applied to ensure the uniform growth of the roots on both sides before proceeding the treatments. The FPRI was only irrigated on the same side; while the APRI was irrigated on both sides alternately, keeping one side dry and the other side moist. The fertilization, weeding and pest removal methods were kept the same in all the treatments.

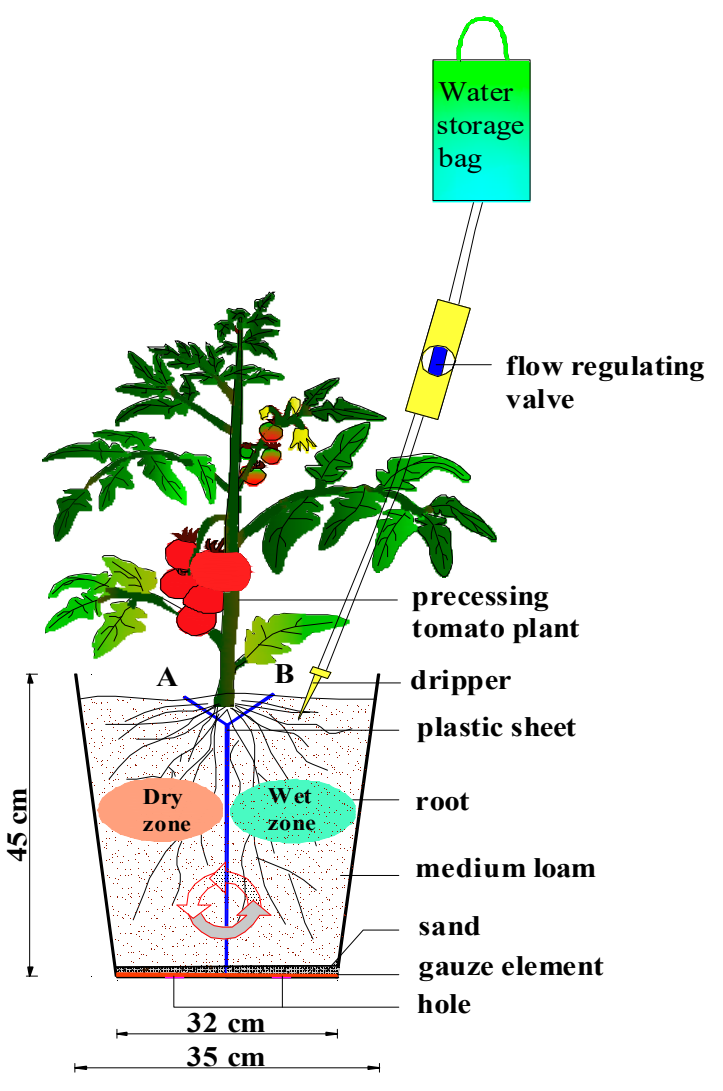

Figure 3. Diagram of roots in the pots.

Water used for irrigation was the local shallow well water in the experimental station, with the salinity of $0.87 \mathrm{~g} \mathrm{~L}^{-1}$. The medical infusion tube was used to simulate the dripper, which could control irrigation amounts of each pot precisely, and the flow rate was $1.80 \mathrm{~L} \mathrm{~h}^{-1}$ (Figure 3). Fertilization was carried out with irrigation and all treatments kept the same management, which was started after $30 \mathrm{~min}$ of irrigation and ended $30 \mathrm{~min}$ before irrigation stopped. The irrigation quota, the number of irrigation times, and the amount of fertilization were referenced to those of the tomato plantation in Shihezi and surrounding farms in recent years. The fertilizers used including urea $(\mathrm{N} 46 \%)$ in $375 \mathrm{~kg} \mathrm{hm}^{-2}$, phosphate monoamine ( $\mathrm{N} \mathrm{12} \%, \mathrm{P}_{2} \mathrm{O}_{5} 62 \%$ ) in $375 \mathrm{~kg} \mathrm{hm}^{-2}$, and potassium chloride $\left(\mathrm{K}_{2} \mathrm{O} 60 \%\right)$ in $525 \mathrm{~kg} \mathrm{hm}^{-2}$. 
Table 2. Processing tomato irrigation schedules during the experiments.

\begin{tabular}{|c|c|c|c|c|c|c|c|c|c|}
\hline \multirow{2}{*}{ Year } & \multirow{2}{*}{ Growth Stage } & \multirow{2}{*}{ Period } & \multicolumn{5}{|c|}{ Irrigation Treatment/mm } & \multirow{2}{*}{$\begin{array}{l}\text { Irrigation } \\
\text { Times }\end{array}$} & \multirow{2}{*}{$\begin{array}{l}\text { Fertilization } \\
\text { Times }\end{array}$} \\
\hline & & & APRIH & APRIM & APRIL & FPRI & CDI & & \\
\hline \multirow{5}{*}{2017} & Seeding & 05/01 05/20 & 67.5 & 51.6 & 43.7 & 67.5 & 67.5 & 1 & 1 \\
\hline & Flowering and fruiting & 05/21 06/15 & 202.5 & 154.8 & 131.1 & 202.5 & 202.5 & 3 & 3 \\
\hline & Fruit expanding & $06 / 16 \sim 07 / 23$ & 337.5 & 258.0 & 218.5 & 337.5 & 337.5 & 5 & 5 \\
\hline & Harvesting & 07/24 08/12 & 67.5 & 51.6 & 43.7 & 67.5 & 67.5 & 1 & 0 \\
\hline & Total & 05/01 08/12 & 675.0 & 516.0 & 437 & 675.0 & 675.0 & 10 & 9 \\
\hline \multirow{5}{*}{2018} & Seeding & $05 / 01 \sim 05 / 22$ & 67.5 & 51.6 & 43.7 & 67.5 & 67.5 & 1 & 1 \\
\hline & Flowering and fruiting & $05 / 23 \sim 06 / 18$ & 202.5 & 154.8 & 131.1 & 202.5 & 202.5 & 3 & 3 \\
\hline & Fruit expanding & 06/19 07/21 & 405.0 & 309.6 & 262.2 & 405.0 & 405.0 & 6 & 6 \\
\hline & Harvesting & 07/22 08/15 & 67.5 & 51.6 & 43.7 & 67.5 & 67.5 & 1 & 0 \\
\hline & Total & 05/01 08/15 & 742.5 & 567.6 & 480.7 & 742.5 & 742.5 & 11 & 10 \\
\hline
\end{tabular}

\subsection{Sampling and Testing Measurements}

\subsubsection{Growth Indices}

Two plants were selected for each treatment, and the plant height and stem diameter were measured every five days and ten days, respectively, with the ruler (measurement accuracy: the ruler measured plant height was $0.05 \mathrm{~mm}$; the ruler measured stem diameter was $0.02 \mathrm{~mm}$ ). Plant height: The natural height from the base of the plant to the growth point of the main stem, measured by a tape measure. Stem thick: A cross stem $3 \mathrm{~cm}$ above the surface of the soil, measured by a digital vernier caliper. Root fresh and dry weights (g), crown fresh and dry weights (g), root-shoot ratio (\%) were measured at the end of the reproductive period. At the end of the experiments, the sampling was obtained by destructively taking processing tomato roots out. The total biomass of the above-ground and the underground parts is the biomass of each plant, and the root-shoot ratio was calculated as the ratio of the underground part dry weight to that of the aerial part.

\subsubsection{Physiological Parameters}

Physiological parameters such as diurnal variation of leaf photosynthesis rate $\left(\mathrm{P}_{\mathrm{n}}\right)$, transpiration rate $\left(T_{r}\right)$ and stomatal conductance $\left(g_{s}\right)$ were measured with a portable photosynthesis system (LI-6400XT, LI-COR Corporation, Lincoln, NE, USA) at a $2 \mathrm{~h}$ interval from 7:00 to 19:00 on cloudless sunny days in the middle of an irrigation interval. This diurnal variation was measured three times with the same healthy leaves at fruit expanding stage. Three fully developed and healthy leaves of different plants in each treatment those were fully exposed to sun were chosen for the measurements. The mean value of every parameter in selected time point of 9:00, 11:00, 15:00, 17:00 and 19:00 was calculated to indicate the leaf gas exchange effectively. The leaf WUE $E_{\text {ins }}$ (instantaneous water use efficiency at leaf scale) was calculated as the ratio of $P_{n}$ to $T_{r}$ and leaf $W U E_{\text {int }}$ (intrinsic water use efficiency at leaf scale) was calculated as the ratio of $P_{n}$ to $g_{s}$.

\subsubsection{Yield and Irrigation Water Use Efficiency}

During the harvesting period, processing tomato fruits were picked four times with an interval of six days when they got bright red luster in each season. Individual fruit weight and total yield were measured using an electronic balance (type: BT-417; measurement accuracy: $0.1 \mathrm{~g}$; manufacturer: Botu, Shenzhen, China). The irrigation water utilization efficiency (iWUE) was calculated as the ratio of yield $\left(\mathrm{kg} \mathrm{hm}^{-2}\right)$ to irrigation quota $\left(\mathrm{m}^{3} \mathrm{hm}^{-2}\right)$.

\subsubsection{Fruit Quality and Shape Indicators}

The matured second spikes were selected for fruit quality tests. Five tomatoes were randomly selected for each treatment. Total soluble solids (TSS) of processing tomato juice were determined using a handheld refractometer (type: PR-32; manufacturer: Atago, Tokyo, Japan) with automatic temperature 
compensation. Organic acid was titrated with $0.1 \mathrm{~mol} \mathrm{~L}^{-1} \mathrm{NaOH}$ and calculated as equivalents of citric acid expressed as percentage of fresh mass [23]. Total soluble sugar content was measured using anthrone method [24]. Vitamin C (ascorbic acid) was measured with the 2,6-dichloroindophenol titrimetric method [25]. Lycopene content was measured at $474 \mathrm{~nm}$ on a spectrophotometer using the modified method [26,27]. Fruit water content was measured using oven-drying method.

The horizontal and vertical diameters of the fruits were determined by digital vernier calipers (type: 91511; measurement accuracy: $0.01 \mathrm{~mm}$; manufacturer: Sata, Shenzhen, China). The transverse diameter coefficient of variation is the ratio of the standard deviation of the transverse diameters to the mean value of the two vertical directions on the fruit plane. The fruit shape index is the ratio of the longitudinal diameter of the tomato to the average transverse diameter.

\subsection{Statistical Analysis}

The experimental data was initially collated by Microsoft Excel 2016, plotted with Origin Pro 2017. Correlation analysis, multi-way analysis of variance (ANOVA) were performed using SPSS 17.0 version soft-ware (SPSS Inc., Chicago, IL, USA), and all treatment means were compared for significant differences using the Duncan's multiple range test at level of $p<0.05$.

\section{Results}

\subsection{Effects of Different Irrigation Methods on Plant Height and Stem Diameter of the Processing Tomato}

The effects of different treatments on pressing tomato plant height and stem diameter are shown in Figure 4.
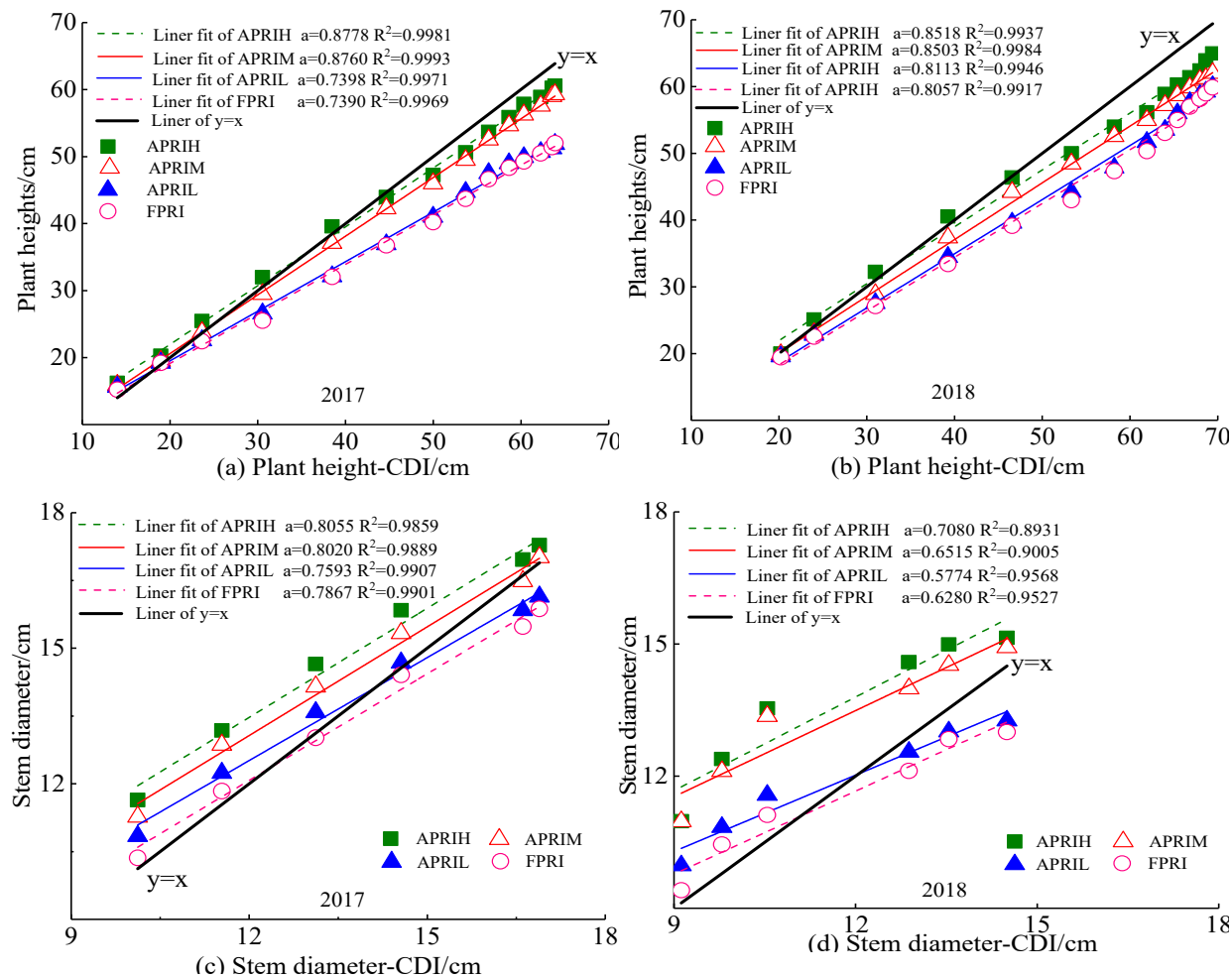

Figure 4. Plant height and stem diameter under different irrigation methods. Note: "a" represents the slope of the fitted line. The fitted straight line indicates the growth rate of plant height $(\mathbf{a}, \mathbf{b})$ and stem diameter $(\mathbf{c}, \mathbf{d})$ relative to conventional drip irrigation (CDI) treatment under alternate partial root-zone irrigation (APRI) and fixed partial root-zoon drip irrigation (FPRI) treatment, and the points indicate the actual measured values of plant height and stem diameter for each treatment, line $\mathrm{y}=\mathrm{x}$ indicates the growth rate of the plant height and stem diameter of the CDI treatment. 
Seen from Figure 4, the heights of processing tomato were $15.62-60.58 \mathrm{~cm}, 15.22-52.02 \mathrm{~cm}$ and 14.01-63.88 cm for three APRI treatments, FPRI treatment and CDI treatment, respectively, in 2017, while comparable values were acquired in 2018 as $19.56-64.98 \mathrm{~cm}, 19.44-59.87 \mathrm{~cm}, 20.21-69.41 \mathrm{~cm}$, respectively. Among all the treatments, CDI showed the largest plant heights in average, and all those of the APRI and FPRI treatments showed significant linear correlations with them. Under the same irrigation quota, the plant height of CDI was larger than APRIH and FPRI in 5.2-6.4\% and $13.8-18.6 \%$ in two years. And with lower irrigation quota, the plant heights of APRIM and APRIL further decreased by $7.2-10.7 \%$ and $13.5-18.3 \%$, respectively.

On the other hand, CDI also obtained the largest stem diameter in average $(9.12-16.89 \mathrm{~mm})$, and all those of the APRI and FPRI treatments still had significant linear correlations with them. As the stem diameter of APRI and FPRI treatments varied within 9.97-17.28 $\mathrm{mm}$ and $9.41-15.87 \mathrm{~mm}$, the stem diameter of APRIH was 2.3-4.4\% larger than CDI, while those of FPRI was 6.0-10.3\% smaller. Besides, the stem diameter of APRIM also increased by $0.7-2.9 \%$ compared to CDI, while that of APRIL decreased by $4.4-8.6 \%$.

In addition, whether it was plant height or stem diameter, the growth rate of three APRI treatment and FPRI treatment was close to and slightly lower than CDI treatment $(y=x)$, probably due to different irrigation methods.

\subsection{Effects of Different Irrigation Methods on Physiological Parameters of the Processing Tomato}

The effects of different treatments on pressing tomato physiological parameters are shown in Table 3.

Table 3. Physiological parameters of the processing tomato under different irrigation methods.

\begin{tabular}{|c|c|c|c|c|c|c|}
\hline Year & Treatment & $\begin{array}{c}P_{n} / \\
\left(\mu \mathrm{mol} \mathrm{m}^{-2} \mathrm{~s}^{-1}\right)\end{array}$ & $\begin{array}{c}\mathrm{T}_{\mathrm{r}} / \\
\left(\mathrm{mmol} \mathrm{m}^{-2} \mathrm{~s}^{-1}\right)\end{array}$ & $\begin{array}{c}\mathrm{g}_{\mathrm{s}} / \\
\left(\mathrm{mol} \mathrm{\textrm {m } ^ { - 2 }} \mathrm{s}^{-1}\right)\end{array}$ & $\begin{array}{c}\text { WUE }_{\text {ins }} / \\
\left(\mu \mathrm{mol} \mathrm{mmol}^{-1}\right)\end{array}$ & $\begin{array}{c}\text { WUE }_{\text {int }} / \\
\left(\mu \mathrm{mol} \mathrm{mmol}^{-1}\right)\end{array}$ \\
\hline \multirow{5}{*}{2017} & APRIH & $14.3 \pm 0.6 \mathrm{a}$ & $2.31 \pm 0.19 \mathrm{ab}$ & $0.48 \pm 0.03 b c$ & $6.2 \pm 0.4 b$ & $29.8 \pm 3.2 \mathrm{a}$ \\
\hline & APRIM & $14.0 \pm 0.7 \mathrm{a}$ & $1.95 \pm 0.22 c$ & $0.52 \pm 0.02 b$ & $7.2 \pm 0.3 a$ & $26.9 \pm 0.3 a$ \\
\hline & APRIL & $12.1 \pm 0.7 \mathrm{~b}$ & $2.15 \pm 0.29 b$ & $0.47 \pm 0.03 b c$ & $5.7 \pm 0.4 b c$ & $25.9 \pm 3.2 b c$ \\
\hline & FPRI & $11.8 \pm 0.6 b$ & $2.44 \pm 0.26 a$ & $0.44 \pm 0.02 c$ & $4.9 \pm 0.2 d$ & $26.9 \pm 0.2 \mathrm{a}$ \\
\hline & CDI & $13.1 \pm 0.7 b$ & $2.38 \pm 0.24 a b$ & $0.60 \pm 0.03 a$ & $5.5 \pm 0.4 c$ & $21.9 \pm 2.3 c$ \\
\hline \multirow{5}{*}{2018} & APRIH & $13.7 \pm 0.7 \mathrm{a}$ & $2.44 \pm 0.34 b$ & $0.45 \pm 0.02 b c$ & $5.6 \pm 0.1 b$ & $30.4 \pm 0.1 \mathrm{a}$ \\
\hline & APRIM & $12.9 \pm 0.7 \mathrm{ab}$ & $2.11 \pm 0.31 d$ & $0.46 \pm 0.03 b$ & $6.1 \pm 0.2 \mathrm{a}$ & $28.1 \pm 0.1 b c$ \\
\hline & APRIL & $11.5 \pm 0.5 c d$ & $2.31 \pm 0.26 c$ & $0.41 \pm 0.02 \mathrm{~cd}$ & $5.0 \pm 0.3 c$ & $28.0 \pm 2.7 \mathrm{bc}$ \\
\hline & FPRI & $10.7 \pm 0.6 \mathrm{~d}$ & $2.65 \pm 0.36 a$ & $0.37 \pm 0.02 \mathrm{~d}$ & $4.0 \pm 0.2 \mathrm{~d}$ & $28.9 \pm 0.1 \mathrm{ab}$ \\
\hline & CDI & $12.4 \pm 0.6 b c$ & $2.59 \pm 0.24 a$ & $0.58 \pm 0.02 a$ & $4.8 \pm 0.1 c$ & $21.4 \pm 0.2 \mathrm{~d}$ \\
\hline
\end{tabular}

Note: The value represents "mean \pm standard deviation" of sample measurement. reduplicate number: $n=3$ for $P_{n}$, $\mathrm{T}_{\mathrm{r}}, \mathrm{g}_{\mathrm{s}}, \mathrm{WUE}_{\text {ins }}$ and $\mathrm{WUE}_{\text {int }}$. Within each treatment, means followed by different letters are significantly different by Duncan's multiple range test at $p<0.05$. The value is "mean \pm standard deviation".

Seen from Table 3, the leaf $\mathrm{P}_{\mathrm{n}}$ of processing tomato were 12.1-14.3 $\mu \mathrm{mol} \mathrm{m}^{-2} \mathrm{~s}^{-1}, 10.7-11.8 \mu \mathrm{mol} \mathrm{m}^{-2} \mathrm{~s}^{-1}$ and 12.4-13.1 $\mu \mathrm{mol} \mathrm{m} \mathrm{m}^{-2} \mathrm{~s}^{-1}$ for three APRI treatments, FPRI treatment and CDI treatment in 2017 and 2018, respectively, with significant difference obtained each year. Compared to CDI and FPRI, there was a significant decrease in leaf $T_{r}$ of APRIH in every year. Besides, significant reductions in leaf $T_{r}$ of APRIM and APRIL were observed, except for APRIL in 2017, compared to APRIH. However, the leaf $g_{s}$ of APRIH was significantly smaller than CDI while larger than FPRI. There was no significant difference in $g_{s}$ among APRI with three different irrigation quotas, except for APRIH and APRIL in 2018. On the other hand, there was a significant reduction in $\mathrm{P}_{\mathrm{n}}$ of lowest irrigation quota (APRIL) compared to APRIH, but neither does APRIM. Compared to CDI, there was a significant increase in $P_{n}$ and decrease in $T_{r}$ and $g_{s}$ of APRIM, while those of APRIL did not reach the significant level.

$W_{U E}$ ins and $W_{U E}$ int showed exactly the same variation trend among different treatments: $\mathrm{WUE}_{\text {ins }} / \mathrm{WUE}_{\mathrm{int}}$ of processing tomato were 5.0-7.2 $\mu \mathrm{mol} \mathrm{mmol}^{-1} / 25.9-29.8 \mu \mathrm{mol} \mathrm{mmol} \mathrm{mm}^{-1}$, $4.0-4.9 \mu \mathrm{mol} \mathrm{mmo}{ }^{-1} / 26.9-28.9 \mu \mathrm{mol} \mathrm{mmol}{ }^{-1}$ and $4.8-5.5 \mu \mathrm{mol} \mathrm{mmol}^{-1} / 21.4-21.9 \mu \mathrm{mol} \mathrm{mmol}^{-1}$ for 
three APRI treatments, FPRI treatment and CDI treatment, respectively. In average, the WUE $\mathrm{ins}_{\text {s }} / \mathrm{WUE}_{\text {int }}$ of APRIH were higher than those of CDI and FPRI under the same irrigation quota. Under the three APRI treatments, compared to APRIM, WUE ins $/ \mathrm{WUE}_{\text {int }}$ was decreased by $13.9 \% / 10.8 \%$ in APRIH with similar $P_{n}$, and increased $\mathrm{T}_{\mathrm{r}}$ by $18.5 \% / 7.7 \%$; while WUE $\mathrm{W}_{\text {ins }}$ in APRIL was decreased by $20.8 \% / 3.7 \%$ with a significant decrease of $\mathrm{P}_{\mathrm{n}}$. WUE Wns $_{\text {int }} / \mathrm{WUE}_{\text {int }}$ increased by $27.1-30.9 \% / 22.8-31.3 \%$ in APRIM compared to those of CDI, while no significant difference were obtained between CDI and APRIL.

\subsection{Effects of Different Irrigation Methods on Fruit Quality of the Processing Tomato}

The effects of different treatments on pressing tomato quality are shown in Table 4.

Seen from the table, the fruit shape index of APRIH was significantly higher than CDI and FPRI in every year. Similarly, the fruit shape index of APRIM was also significantly higher than CDI, but a reduction in APRIL compared to CDI in every year. There was no significant difference in fruit water content between APRIH and CDI, but they both significantly larger than the others. The water contents of APRIM and APRIL was significantly decreased by $12.4-12.9 \%$ and $18.4-18.5 \%$, respectively, and meanwhile, no significant difference were obtained between APRIL and FPRI. On the other hand, in the sugar-acid ratio between APRIH and CDI were similar, and along with those of APRIM and APRIL, all significantly larger than that of FPRI.

Among the nutritional qualities of processing tomato (including soluble solid, Vc and lycopene), there was significant difference observed in neither soluble solid nor Vc between APRIH and CDI, except for Vc in 2018. Meanwhile, the lycopene of APRIH increased by $6.0-8.2 \%$ compared to that of CDI. On the other hand, soluble solid, Vc and lycopene of FPRI all decreased significantly in comparison with those of CDI. Although decreasing the irrigation quota to APRIL showed significant impact on the reduction of soluble solid, Vc and lycopene, APRIM did not show significant changes in soluble solid, and its Vc and lycopene increased instead.

Table 4. Processing tomato qualities under different treatments.

\begin{tabular}{cccccccc}
\hline Year & Treatment & $\begin{array}{c}\text { Fruit Shape } \\
\text { Index }\end{array}$ & $\begin{array}{c}\text { Water } \\
\text { Content/(g) }\end{array}$ & $\begin{array}{c}\text { Sugar-Acid } \\
\text { Ratio/(\%) }\end{array}$ & $\begin{array}{c}\text { Soluble } \\
\text { Solid/(\%) }\end{array}$ & Vc/(mg 1000 g) & Lycopene/( $\boldsymbol{\mu g} \mathbf{g} \mathbf{- 1})$ \\
\hline \multirow{6}{*}{2017} & APRIH & $0.748 \pm 0.002 \mathrm{~b}$ & $95.65 \pm 2.11 \mathrm{a}$ & $5.92 \pm 0.16 \mathrm{bc}$ & $6.23 \pm 0.64 \mathrm{a}$ & $20.33 \pm 0.54 \mathrm{~b}$ & $72.31 \pm 2.06 \mathrm{~b}$ \\
& APRIM & $0.774 \pm 0.002 \mathrm{a}$ & $85.62 \pm 2.41 \mathrm{~b}$ & $6.32 \pm 0.08 \mathrm{a}$ & $6.59 \pm 0.28 \mathrm{a}$ & $22.63 \pm 1.49 \mathrm{a}$ & $75.26 \pm 0.95 \mathrm{a}$ \\
& APRIL & $0.741 \pm 0.005 \mathrm{~d}$ & $80.22 \pm 1.63 \mathrm{c}$ & $6.06 \pm 0.19 \mathrm{ab}$ & $5.88 \pm 0.14 \mathrm{~b}$ & $15.62 \pm 0.51 \mathrm{c}$ & $65.21 \pm 1.63 \mathrm{~d}$ \\
& FPRI & $0.738 \pm 0.003 \mathrm{~d}$ & $78.36 \pm 1.85 \mathrm{c}$ & $5.51 \pm 0.12 \mathrm{~d}$ & $5.32 \pm 0.27 \mathrm{~b}$ & $14.27 \pm 0.73 \mathrm{c}$ & $62.32 \pm 1.73 \mathrm{e}$ \\
& CDI & $0.743 \pm 0.006 \mathrm{bc}$ & $98.26 \pm 1.75 \mathrm{a}$ & $5.74 \pm 0.23 \mathrm{~cd}$ & $6.49 \pm 0.38 \mathrm{a}$ & $18.56 \pm 1.30 \mathrm{~b}$ & $68.22 \pm 1.24 \mathrm{c}$ \\
\hline \multirow{6}{*}{2018} & APRIH & $0.740 \pm 0.001 \mathrm{~b}$ & $96.22 \pm 1.97 \mathrm{a}$ & $5.34 \pm 0.14 \mathrm{~b}$ & $5.88 \pm 0.14 \mathrm{~b}$ & $18.55 \pm 0.10 \mathrm{~b}$ & $69.88 \pm 2.47 \mathrm{a}$ \\
& APRIM & $0.755 \pm 0.001 \mathrm{a}$ & $87.45 \pm 2.04 \mathrm{~b}$ & $5.94 \pm 0.10 \mathrm{a}$ & $6.35 \pm 0.19 \mathrm{a}$ & $20.37 \pm 1.17 \mathrm{a}$ & $72.63 \pm 0.91 \mathrm{a}$ \\
& APRIL & $0.730 \pm 0.001 \mathrm{c}$ & $81.36 \pm 1.89 \mathrm{c}$ & $5.72 \pm 0.11 \mathrm{a}$ & $5.41 \pm 0.18 \mathrm{c}$ & $13.25 \pm 0.59 \mathrm{~d}$ & $62.44 \pm 2.19 \mathrm{~b}$ \\
& FPRI & $0.722 \pm 0.002 \mathrm{~d}$ & $79.67 \pm 1.92 \mathrm{c}$ & $5.04 \pm 0.15 \mathrm{c}$ & $5.04 \pm 0.20 \mathrm{~d}$ & $12.36 \pm 0.48 \mathrm{~d}$ & $58.65 \pm 1.67 \mathrm{c}$ \\
& CDI & $0.732 \pm 0.002 \mathrm{c}$ & $99.87 \pm 2.77 \mathrm{a}$ & $5.22 \pm 0.19 \mathrm{bc}$ & $6.12 \pm 0.11 \mathrm{ab}$ & $16.38 \pm 0.96 \mathrm{c}$ & $64.59 \pm 2.28 \mathrm{~b}$ \\
\hline
\end{tabular}

Note: sugar-acid ratio was calculated as the ratio of soluble sugar to organic acid.

\subsection{Effects of Different Irrigation Methods on Yield Irrigation Water Use Efficiency of the Processing Tomato}

The effects of different treatments on pressing tomato yield and iWUE are shown in Table 5.

As shown in Table 5, yield of APRIH significantly increased by 10.3\% and 3.5\% in 2017 and 2018, respectively, compared to CDI, while those of FPRI significantly decreased by $28.7 \%$ and $34.9 \%$, respectively. APRIM also showed higher yield than CDI but not to the significant level. Significant reduction in APRIL were obtained as its yield decreased by $29.5-36.0 \%$.

On the other hand, the iWUE of APRIH was also significantly higher than CDI, while that of FPRI was still significantly lower. However, different from the yield, the iWUE of APRIM reached the largest numver, which increased by 31.8-32.7\% in comparison with CDI. Besides, the iWUE of APRIL was slightly higher than CDI in 2017, but lower than CDI in 2018, without any significant differences. 
Table 5. Yield and iWUE under different irrigation treatments.

\begin{tabular}{ccccc}
\hline Year & Treatment & Irrigation Amount/(mm) & Yield/(g plant $\left.{ }^{-\mathbf{1}}\right)$ & iWUE/(g (mm plant) $\left.^{\mathbf{- 1}}\right)$ \\
\hline \multirow{4}{*}{2017} & APRIH & 675.0 & $1958.36 \pm 25.80 \mathrm{a}$ & $2.90 \pm 0.04 \mathrm{~b}$ \\
& APRIM & 516.0 & $1802.69 \pm 46.93 \mathrm{~b}$ & $3.49 \pm 0.094 \mathrm{a}$ \\
& APRIL & 437.0 & $1252.48 \pm 27.52 \mathrm{c}$ & $2.87 \pm 0.064 \mathrm{~b}$ \\
& FPRI & 675.0 & $1266.35 \pm 21.34 \mathrm{c}$ & $1.88 \pm 0.034 \mathrm{~d}$ \\
& CDI & 675.0 & $1775.26 \pm 20.94 \mathrm{~b}$ & $2.63 \pm 0.03 \mathrm{c}$ \\
\hline \multirow{2}{*}{2018} & APRIH & 742.5 & $1804.58 \pm 40.68 \mathrm{a}$ & $2.678 \pm 0.06 \mathrm{~b}$ \\
& APRIM & 567.6 & $1754.82 \pm 29.50 \mathrm{ab}$ & $3.40 \pm 0.06 \mathrm{a}$ \\
& APRIL & 480.7 & $1115.36 \pm 20.85 \mathrm{c}$ & $2.55 \pm 0.05 \mathrm{c}$ \\
& FPRI & 742.5 & $1135.62 \pm 28.90 \mathrm{c}$ & $1.68 \pm 0.04 \mathrm{~d}$ \\
& CDI & 742.5 & $1743.22 \pm 26.65 \mathrm{~b}$ & $2.58 \pm 0.04 \mathrm{bc}$ \\
\hline
\end{tabular}

\section{Discussion}

Through the paper, the effects of different irrigation methods on growth indices, physiological parameters, yield, fruit quality and iWUE of the processing tomato were systematically studied. By regulating the amount of irrigation water and spatial distribution within the micro-domains around root zones, plant growth could be well promoted [28]. In this study, plant height and stem diameter (except APRIH and APRIM) decreased significantly in APRI and FPRI treatments comparing with CDI treatment, which may affect dry matter accumulation and the formation of yield [28]. The stem growth not only reflects the distribution of assimilation products, but also provides basic conditions for high-yield and high-quality fruits. However, higher plant height does not mean higher yield nor water use efficiency. Although deep roots of plants can synthesize large amounts of assimilation products, the large amounts of nutrients needed also indicates that it is not cost-optimal. On the contrary, by applying irrigation method like APRI, a reasonable smaller plant could reduce the consumption of nutrients, and meanwhile obtain reasonable high quality and yield [29]. APRI alternated the wetted and dried sides of the root-zone with less irrigation water, with the potential to reduce plant "luxury" water use, decrease canopy vigour and maintain the balance between vegetative and reproductive growth with reduced redundancy growth [9].

Quite a few studies have shown that fertilizer and moisture are the main factors affecting the crop qualities. Sufficient or overload irrigation increases the yield, but reduces the content of soluble substances such as sugar and organic acids in the fruit [30]. Therefore, in recent years, deficit irrigation is attracting more attention as it aims to improve the quality of fruit by controlling soil moisture to give crops a moderate drought stress [31,32]. In this experiment, the results also indicated that the high and medium irrigation quota of APRI had improved the quality of processing tomatoes to certain extents, and among them, medium irrigation quota (APRIM) showed better improvement. Therefore, if the irrigation quota is well controlled to the appropriate range, applying APRI can significantly improve the quality of processed tomato and save irrigation water, which FPRI can not accomplish. During the process, moisture is the most important and most active fertility and environmental factor in crop production. On the other hand, the comprehensive quality of processing tomato decreased in 2018, which difference resulted from the growth stage under different weather conditions.

Meanwhile, pressing tomato yield and iWUE were greatly affected in APRI as compared with CDI and FPRI, especially with APRIM treatment (Table 5). In the 2-year experiment, yield of APRIH increased by $3.5-10.3 \%$ compared to CDI, and APRIM slightly higher than CDI; while APRIM reached the maximum iWUE among 5 treatments, which was 32.7-31.8\% larger than CDI. These results obtained were similar to the results reported using with the APRI in eggplant [33]. APRI could create a dry-and-wet cycle in the root-zone soil [34,35]. As an adaptive response to drought, roots develop specific metabolic adaptations to uptake water and nutrients [36]. In the specific water environment of APRI, since the root of the dry side can produce ABA [37], the signal is transmitted to cause the leaf pores to close, which can reduce the amount of water lost by transpiration. The wet side of the plant 
offers sufficient water, and the plant has never been subjected to the pressure of defects like traditional irrigation methods, which was confirmed by several reports on woody and herbaceous species $[38,39]$. When the other part of the crop roots subjected to water stress, ABA continuously produced in the root system and transmitted to the leaves through the xylem juice to adjust the stomatal opening $[40,41]$. Under this condition, ABA was increased in the root system located in the dry area. The feedback affected the leaf stomatal opening, reducing transpiration without reducing photosynthesis, and achieved the purpose of water-saving without affecting photosynthesis substantially [42-44]. These features could account for the stable yield of processing tomato in the APRI treatments under deficit irrigation [33]. In general, relatively lower irrigation level was accompanied with higher WUE and yield with APRI. This study showed that APRIM could achieve the best balance.

\section{Conclusions}

Although all three APRI treatments decreased the plant height, it improved yield of processing tomato significantly without negative impacts on fruit quality, with the same irrigation quota of CDI $(67.5 \mathrm{~mm})$, as it enlarged stem diameter and enhanced the photosynthetic process. Therefore, APRI demonstrated an appropriate high-efficiency and water-saving method in processing tomato plantation in arid desert area such as Xinjiang. Furthermore, among the APRI treatments, medium irrigation quota of APRIM $(51.6 \mathrm{~mm}$ ) also increased iWUE by $31.8-32.7 \%$ by saving the irrigation water of $23.6 \%$. As APRIM showed better performance with comprehensive consideration of plant growth, photosynthetic parameters, fruit quality, yield, and iWUE, than those of APRIH ( $67.5 \mathrm{~mm})$ and APRIL $(43.7 \mathrm{~mm})$, it is recommended for processing tomato plantation. Further studies may focus more on the fertilization mode and different growth stages in the yield to have a better understanding of the mechanism of APRI with controlled medium irrigation quota.

\section{Abbreviations}

$\begin{array}{ll}\text { APRI } & \text { Alternate partial root-zoon drip irrigation } \\ \text { APRIH } & \text { Alternate partial root-zoon drip irrigation with high irrigation quota } \\ \text { APRIM } & \text { Alternate partial root-zoon drip irrigation with medium irrigation quota } \\ \text { APRIL } & \text { Alternate partial root-zoon drip irrigation with low irrigation quota } \\ \text { FPRI } & \text { Fixed partial root-zoon drip irrigation } \\ \text { CDI } & \text { Conventional drip irrigation } \\ P_{n} & \text { Diurnal variation of leaf photosynthesis rate } \\ \mathrm{T}_{\mathrm{r}} & \text { Transpiration rate } \\ \mathrm{g}_{\mathrm{s}} & \text { Stomatal conductance } \\ \mathrm{WUE}_{\text {ins }} & \text { Instantaneous water use efficiency at leaf scale } \\ \text { WUE }_{\text {int }} & \text { Intrinsic water use efficiency at leaf scale } \\ \text { iWUE } & \text { Irrigation water utilization efficiency }\end{array}$

Author Contributions: Z.W. and J.Z. provided the idea of the study and writing of the manuscript, D.Z. conducted the data analysis, B.Z. and W.L. provided important advice on the concept of the methodology.

Funding: This research received no external funding.

Acknowledgments: We are grateful for the financial support from the National Key R\&D Program "Research and Application of Economic Crop Water and Fertilizer Integration Technology Model" (2017YFD0201506), and Shihezi University International Science and Technology Cooperation Promotion Project "Study on Water Requirement Characteristics and Water-Salt Movement Law of Drip Irrigation Processing in Northern Xinjiang (GJHZ201803)", Water-saving Irrigation Experiment Project of the Corps "Processing Tomato Crop Coefficient $(\mathrm{Kc})$ and Irrigation System in Shihezi Reclamation Area Research (BTJSSY-201807), the Bing Tuan Water-saving Irrigation Experiment Project "Twelfth Division Processing Tomato Crop Coefficient $(\mathrm{Kc})$ and Irrigation System Research (BTJSSY-201811)".

Conflicts of Interest: The authors declare no conflict of interest. 


\section{References}

1. Liu, C. Analysis on the status quo and development prospect of processing tomato industry in Xinjiang. Mod. Food. 2018, 13, 4, 5, 9. (In Chinese with English abstract).

2. Yang, S.; Tang, Y.; Yang, T.; Xu, J.; Li, N.; Pa, T.; Gao, J.; Yu, Q. Fruit characteristic and flesh tissue feature of special firmness type processing tomato cultivar. Chin. Soc. Agric. Eng. 2017, 33, 285-290. (In Chinese with English abstract).

3. Ming, H.; Zhao, C.; Feng, G.; Yan, Y.; Yu, S. Evaluating the effects of mulch and irrigation amount on soil water distribution and root zone water balance using HYDRUS-2D. Water 2015, 7, 2622-2640.

4. Kang, S.; Zhang, J.; Liang, Z.; Hu, X.; Cai, H. The controlled alternative irrigation: A new approach for water saving regulation in farmland. Agric. Res. Arid Areas. 1997, 15, 1-6.

5. Wang, J.; Niu, W.; Zhang, M.; Li, Y. Effect of alternate partial root-zone drip irrigation on soil bacterial communities and tomato yield. Appl Soil. Ecol. 2017, 119, 250-259. [CrossRef]

6. Tombesi, S.; Nardini, A.; Frioni, T.; Soccolini, M.; Zadra, C.; Farinelli, D.; Poni, S.; Palliotti, A. Stomatal closure is induced by hydraulic signals and maintained by ABA in drought-stressed grapevine. Sci. Rep. 2015, 5, 12449. [CrossRef] [PubMed]

7. Dodd, I.C. Abscisic acid and stomatal closure: A hydraulic conductance conundrum? New Phytol. 2012, 197, 6-8. [CrossRef] [PubMed]

8. Wilkinson, S.; William, J.; Drought, O. ABA and ethylene: new insights from cell to plant to community. Plant. Cell Env. 2010, 33, 510-525. [CrossRef]

9. Du, T.; Kang, S.; Zhang, J.; Li, F. Water use and yield responses of cotton to alternate partial root-zone drip irrigation in the arid area of north-west China. Irrig. Sci. 2008, 26, 147-159. [CrossRef]

10. Du, S.; Kang, S.; Li, F.; Du, T. Water use efficiency is improved by alternate partial root-zone irrigation of apple in arid northwest China. Agric. Water Manag. 2017, 179, 184-192. [CrossRef]

11. Du, S.; Ling, T.; Ding, R.; Kang, S.; Li, S.; Du, T.; Zhang, X. Signal intensity based on maximum daily stem shrinkage can reflect the water status of apple trees under alternate partial root-zone irrigation. Agric. Water Manag. 2017, 190, 21-30. [CrossRef]

12. Ma, Y.; Homstrm, C.; Webb, J.; Kjelleberg, S. Application of denaturing gradient gel electrophoresis (DGGE) in microbial ecology. Acta Ecol. Sin. 2003, 23, 1561-1569.

13. Yang, Q.; Zhang, F.; Li, F.; Liu, X. Hydraulic conductivity and water-use efficiency of young pear tree under alternate drip irrigation. Agric. Water Manag. 2013, 119, 80-88. [CrossRef]

14. Liang, H.; Li, F.; Nong, M. Effects of alternate partial root-zone irrigation on yield and water use of sticky maize with fertigation. Agric. Water Manag. 2013, 116, 242-247. [CrossRef]

15. Wang, Z.; Liu, F.; Kang, S.; Jensen, C.R. Alternate partial root-zone drying irrigation improves nitrogen nutrition in maize (Zea mays L.) leaves. Environ. Exp. Bot. 2012, 75, 36-40. [CrossRef]

16. Du, T.; Kang, S.; Zhang, J.; Li, F.; Yan, B. Water use efficiency and fruit quality of table grape under alternate partial root-zone drip irrigation. Agric. Water Manag. 2008, 95, 659-668. [CrossRef]

17. Du, T.; Kang, S.Z.; Yan, B.Y.; Zhang, J.H. Alternate furrow irrigation: A practical way to improve grape quality and water use efficiency in arid Northwest China. J. Integr. Agric. 2013, 12, 509-519. [CrossRef]

18. Parvizi, H.; Sepaskhah, A.R.; Ahmadi, S.H. Effect of drip irrigation and fertilizer regimes on fruit yields and water productivity of a pomegranate (Punica granatum (L.) cv. Rabab) orchard. Agric. Water Manag. 2015, 156, 70-78. [CrossRef]

19. Topak, R.; Acar, B.; Uyanoz, R.; Ceyhan, E. Performance of partial root-zone drip irrigation for sugar beet production in a semi-arid area. Agric. Water Manag. 2016, 176, 180-190. [CrossRef]

20. Yactayo, W.; Ramirez, D.A.; Gutierrez, R.; Mares, V.; Posadas, A.; Quiroz, R. Effect of partial root-zone drying irrigation timing on potato tuber yield and water use efficiency. Agric. Water Manag. 2013, 123, 65-70. [CrossRef]

21. Sun, Y.; Holm, P.E.; Liu, F. Alternate partial root-zone drying irrigation improves fruit quality in tomatoes. Hortic. Sci. 2018, 41, 185-191. [CrossRef] 
22. Wei, Z.; Du, T.; Zhang, J.; Xu, S.; Cambre, P.J.; Davies, W.J. Carbon isotope discrimination shows a higher water use efficiency under alternate partial root-zone irrigation of field-grown tomato. Agric. Water Manag. 2016, 165, 33-43. [CrossRef]

23. AOAC. Official Methods of Analysis, 15th ed.; Association of Official Analytical Chemists: Washington, DC, USA, 1990.

24. Ryčkov, G.S. Analysis of sugars found in glycoproteins. Method. Enzymol. 1966, 8, 3-26.

25. AOAC. Vitamin C (Ascorbic Acid) in Vitamin Preparations and Juices: 26-Dichloroindophenol Titrimetric Method; Association of Official Analytical Chemists: Washington, DC, USA, 1984; pp. 844-845.

26. Goodwin, T.W. Chemistry and Biochemistry of Plant Pigments; Academic Press: Cambridge, MA, USA, 1965.

27. Sharma, S.K.; Maguer, M.L. Lycopene in tomatoes and tomato pulp fractions. Ital. J. Food Sci. 1996, 8, 107-113.

28. Hu, X.; Kang, S.; Zhang, J.; Zhang, F.; Li, Z.; Zhou, L. Water-saving mechanism and efficiency of vertical partial-rootzone alternative controlled drip irrigation of tomato (Lycopersicon Esculentum). J. Agric. Eng. 2005, 21, 1-5. (In Chinese with English abstract).

29. Lin, Y.; Zeng, Z.; Ren, C.; Yuegao, H.U. Water use efficiency and physiological responses of oat under alternate partial root-zone irrigation in the semiarid areas of Northeast China. Procedia Eng. 2012, 28, $33-42$.

30. Baselga, Y.J.J.; Prieto, L.M.H.; Rodriguez, D.R.A. Response of processing tomato to three different levels of water and nitrogen applications. Int. Symp. Irrig. Hortic. Crop. 1992, 335, 149-156.

31. Mitchell, J.P.; Shennan, C.; Grattan, S.R.; May, D.M. Tomato fruit yields and quality under water deficit and salinity. J. Am. Soc. Hortic. Sci. 1991, 116, 215-221. [CrossRef]

32. Payero, J.O.; Melvin, S.R.; Irmak, S.; Tarkalson, D. Yield response of corn to deficit irrigation in a semiarid climate. Agric. Water Manag. 2006, 84, 101-112.

33. Zhang, Q.; Wu, S.; Chen, C.; Shu, L.Z.; Zhou, X.J.; Zhu, S.N. Regulation of nitrogen forms on growth of eggplant under partial root-zone irrigation. Agric. Water Manag. 2014, 142, 56-65. [CrossRef]

34. Aujla, M.S.; Thind, H.S.; Buttar, G.S. Fruit yield and water use efficiency of eggplant as influenced by different quantities of nitrogen and water applied through drip and furrow irrigation. Sci. Hortic. 2007, 112, 142-148. [CrossRef]

35. Zhang, L.; Gao, L.; Zhang, L.; Wang, S.; Sui, X.; Zhang, Z. Alternate furrow irrigation and nitrogen level effects on migration of water and nitrate-nitrogen in soil and root growth of cucumber in solar-greenhouse. Sci. Hortic. 2004, 99, 43-49. [CrossRef]

36. Gargallogarriga, A.; Sardans, J.; Rivasubach, A.; Oravec, M.; Vecerova, K.; Urban, O.; Jentsch, A.; Kreyling, J.; Beierkuhnlein, C.; Parella, T. Opposite metabolic responses of shoots and roots to drought. Sci. Rep. 2014, 4, 6829. [CrossRef]

37. Giorio, P.; Sorrentino, G.; Andria, R.D. Stomatal behaviour, leaf water status and photosynthetic response in field-grown olive trees under water deficit. Environ. Exp. Bot. 1999, 42, 95-104. [CrossRef]

38. Pospíšilová, J. Interaction of cytokinins and abscisic acid during regulation of stomatal opening in bean leaves. Photosynthetica 2003, 41,49-56. [CrossRef]

39. Tardieu, F.J.; Zhang, J.T.; Gowing, D.J.G. Stomatal control by both [ABA] in the xylem sap and leaf water status: A test of a model for droughted or ABA-fed field-grown maize. Plant. Cell Environ. Behav. 2010, 16, 413-420. [CrossRef]

40. Davies, W.; Zhang, J. Root signals and the regulation of growth and development of plants in drying soil. Annu. Rev. Plant. Biol. 1991, 42, 55-76. [CrossRef]

41. Zhang, J.; Davies, W.J. Sequential response of whole plant water relations to prolonged soil drying and the involvement of xylem sap ABA in the regulation of stomatal behavior of sunflower plants. New Phytol. 1989, 113, 167-174. [CrossRef]

42. Kang, S.; Zhang, L.U.; Xiaotao, H.U.; Zhijun, L.I.; Jerie, P. An improved water use efficiency for hot pepper grown under controlled alternate drip irrigation on partial roots. Sci. Hortic. 2001, 89, 257-267. [CrossRef] 
43. Aganchich, B.; Wahbi, S.; Loreto, F.; Centritto, M. Partial root zone drying: Regulation of photosynthetic limitations and antioxidant enzymatic activities in young olive (Olea europaea) saplings. Tree Physiol. 2009, 29, 685-696. [CrossRef]

44. Li, F.; Liang, J.; Kang, S.; Zhang, J. Benefits of alternate partial root-zone irrigation on growth, water and nitrogen use efficiencies modified by fertilization and soil water status in maize. Plant Soil 2007, 295, 279-291. [CrossRef] 